'Table 1. FIRST EMPLOYMENT OF HIGHER DEGREE GRADUATES IN THE USA

\begin{tabular}{|c|c|c|c|c|c|c|c|c|c|}
\hline Field of doctorate & $\begin{array}{c}\text { Year of } \\
\text { doctorate }\end{array}$ & $\begin{array}{c}\text { Collego } \\
\text { and } \\
\text { university }\end{array}$ & $\begin{array}{l}\text { Elementary } \\
\text { and } \\
\text { secondary } \\
\text { school }\end{array}$ & $\begin{array}{l}\text { Govern- } \\
\text { ment }\end{array}$ & $\begin{array}{l}\text { Non- } \\
\text { profit }\end{array}$ & Industry & Other & $\begin{array}{l}\text { Eoreign } \\
\text { einployer }\end{array}$ & $\begin{array}{c}\text { Total with } \\
\text { known } \\
\text { employer }\end{array}$ \\
\hline \multirow[t]{2}{*}{ Total all fiolds } & $1961-63$ & 18,877 & 1,722 & 2,410 & 1,305 & 4,319 & 763 & 2,828 & 32,224 \\
\hline & $1964-66$ & 27,362 & 2,082 & 2,921 & 1,760 & 5,499 & 1,127 & 3,961 & 44,712 \\
\hline \multirow{2}{*}{$\begin{array}{l}\text { Physical sciences } \\
\text { and engineering }\end{array}$} & $1961-63$ & 4,643 & 27 & 598 & 374 & 3,521 & 345 & 912 & 10,420 \\
\hline & $1964-66$ & 7,259 & 5 & 845 & 498 & 4,540 & 597 & 1,338 & 15,082 \\
\hline \multirow[t]{2}{*}{ Biological sciences } & $1961-63$ & 3,096 & 33 & 640 & 193 & $\begin{array}{r}1,040 \\
442\end{array}$ & 126 & $\begin{array}{r}1,000 \\
808\end{array}$ & $\begin{array}{r}10,002 \\
5,338\end{array}$ \\
\hline & $1964-66$ & 4,255 & 4 & 776 & 289 & 516 & 184 & 1,135 & 7,159 \\
\hline Social sciences & $1964-66$ & 4,328 & $\begin{array}{r}170 \\
82\end{array}$ & 833 & 497 & 255 & 203 & 610 & 6,808 \\
\hline
\end{tabular}

are attracted each year. This trend is especially marked in the physical sciences and engineering. Industry is the major employer of physical scientists and engineers, but it employs fewer than 10 per cent in other fields. The percentage of scientists and engineers with doctorates going into industry, however, has fallen rapidly from 44 per cent in $1958-60$ to 30 per cent in 1964-66. Mathematics, physics and chemistry show especially sharp declines in industrial employment. Fewer than 10 per cent of the new higher degree graduates accepted employment overseas, but this figure should be balanced against the number of foreign graduate students ( 14 per cent) in the country. Brain drain enthusiasts should have fun working on all these figures.

\section{No Merger for Engineers}

Tru projected merger between the Institution of Mechanical Engineers and the Institution of Heating and Ventilating Engineers is off. After discussions lasting the best part of a year, the heating and ventilat ing engineers finally decided that they no longer wished to press on with the merger. The decision has left the mechanical engineers slightly baffled. "We don't know why they decided against the merger" an official said this week. "It's very disappointing."

Merger talks began when the heating and ventilating ongineers decided that they wanted to increase their influence. The easiest way of doing this, short of a royal charter which was very unlikely to be granted, was to amalgamate with an established body. The obvious choice was the Institution of Mechanical Engineers, and talks began. It was first agreed that the heating and ventilating engineers should enjoy a status within the combined institution much like that enjoyed by the automobile engineers. They would have been virtually an autonomous group, with their own council and their own chairman, and members in the different classes of membership in the IHVE would have been able to transfer to the equivalent classes in the combined body. The IHVE would have been able to publish its own journals and hold its own conferences and meetings. The mechanical engineers had agreed to set up joint working parties to study the problem of technician engineers, whose position the IHVE was anxious to protect. Despite all this, the heating and ventilating engineers told the mechanicals on December 20 that they did not wish to proceed.

One heating engincer suggested this week that the IHVE feared that it would be swamped when it joined the mechanicals. There does seem to have been some opposition within the profession, although the mechanical engineers say that they have received several letters from individual members of the IHVE regretting the decision. The Institution of Mechanical Engineers denies that it ever wanted to make a takeover bid for the IHVE, and "sincerely hopes that this is not the end of the affair. The door is not closed to further talks". Meanwhile, joint meetings will continue as before. Clearly the hope is that the IHVE will eventually see the folly of its ways.

\section{Safety in Space}

\section{by Angela Croome}

SEvere strictures on National Aeronautics and Space Administration (NASA) complacency, which it considers was responsible for the deaths of three astronauts in last year's Apollo fire, are contained in the Congressional report of its own inquiry into the circumstances of the accident. Some of the Senate space committee are doubtful if the shortcomings of the contractors' work would have come to light without the accident, and NASA is criticized for not passing on to Congress reservations on the performance of the Apollo main contractor, North American Aviation, which was the subject of a secret NASA report in 1965. In summary, "NASA's performance-the evasiveness, the lack of candour, the patronizing attitude exhibited towards Congress, the refusal to respond fully and forthrightly to legitimate congressional inquiries, and the solicitous concern for corporate sensitivities at a time of national tragedy-can only produce a loss of congressional and public confidence in NASA programmes".

In the meantime, extensive replacement of materials in the capsule and spacesuit to make these "almost fireproof" has been completed. A quick escape hatch has been substituted for the previous design. The total cost of these modifications is estimated at $\$ 100$ million. The changes have forced the forfeit of between 600 $1,000 \mathrm{lb}$. in the overall weight of the spacecraft and this in turn has required the re-design of the return parachute system to support it. A fully fire-resistant material, Beta fabric, has replaced high-temperature nylon (Nomex) for the outer layer of the Apollo pressure-suit. The inflammable boot-soles and helmet (polyurethanc) have been replaced by carboxy-nitroso rubber and a silicone material respectively. Nomex has been substituted for nylon as the material of the suit liner. The opportunity has been taken to make the suit more comfortable and durable. Metallized patches oover pressure points and the outside of the gloves are equipped with artificial nails or claws to assist sample collection. It is estimated that about 1,000 yards will be the walking limit of an astronaut kitted out for the first lunar excursion.

On its first flight on January 23 the Apollo lunar model acquitted itself well, and NASA authorities are 